\title{
Workers' health disorders: Burnout syndrome on public servers
}

\section{Pamela Acosta-Rodas ${ }^{1}$, Caterina Frattessi-Zambrano², Janio Jadán-Guerrero² ${ }^{2}$, and Carlos Ramos-}

\section{Galarza $^{1,2}$}

1. Facultad de Psicología, Pontificia Universidad Católica del Ecuador, Quito, Ecuador

2. Centro de Investigación MIST, Universidad Tecnológica Indoamérica, Quito, Ecuador

\section{RESEARCH}

Please cite this paper as: Acosta-Rodas $\mathrm{P}$, Fratessi-Zambrano C, Jadán-Guerrero J, Ramos-Galarza C. Workers' health disorders: Burnout syndrome on public servers. AMJ 2018;11(6):343-351.

https://doi.org/10.21767/AMJ.2018.3426

\section{Corresponding Author:}

Carlos Ramos-Galarza, PhD. Principal, Professor

Faculty of Psychology

Pontifical Catholic University of Ecuador

Ecuador

Email: caramos@puce.edu.ec

\section{ABSTRACT}

\section{Background}

Burnout syndrome encompasses emotional tiredness, depersonalization and the sense of low personal fulfilment.

\section{Aims}

The aim of this study is to analyse Burnout syndrome on public servers.

\section{Methods}

Participants were 121 employees of public institutions, where 46 were females (38.02 per cent) and 75 males (61.98 per cent), aged between 24 and 58 years (Mage=36.21, SD=7.98). As measurement regent Maslach Burnout Inventory General Survey was applied. As statistical analyses descriptive techniques of central tendency and dispersion were conducted. Inferential analyses encompassed correlation techniques, variance comparison and risk factor prediction.

Results

There were found significant correlations among Burnout dimensions: (a) emotional tiredness, (b) depersonalization, and (c) low personal fulfilment $(r=0.32-0.63)$. Between 5 per cent and 20 per cent of workers presented a high risk to present Burnout's symptomatology. Male gender presented 1.39 (IC 0.61-3.15) and 1.12 (IC 0.48-2.60) times more probability to present low personal fulfilment and depersonalization respectively. Females presented 1.39 (IC 0.61-3.15) times more probability to present emotional tiredness. According to educational level, workers with secondary level presented lower personal fulfilment $(F=4.33, p=0.002)$ than those with higher educational level.

\section{Conclusion}

Analyses of data in relationship with previous studies are realized, highlighting the need to implement future interventions in order to diminish the risk for a public server to present the Burnout syndrome.

\section{Key Words}

Burnout syndrome, psychology, public sector, work-related stress

\section{What this study adds:}

\section{What is known about this subject?}

The study of stressors allows understanding worker's performance at job on public sector.

\section{What new information is offered in this study?}

There is an analysis of the association among Burnout syndrome and worker's from public sector socio demographic factors.

3. What are the implications for research, policy, or practice?

In this study factors that must be attended in mental health programs for public servers are identified.

\section{Background}

Burnout term was introduced in scientific literature in 1980 by the psychologist Freudenbergeren ${ }^{1}$ and it has been 
deeply studied by Maslach, ${ }^{2}$ who proposed that Burnout means "to be burned", making reference to a kind of organizational and work-related stress.

This syndrome is an answer to a chronic work-related stress which appears when coping strategies that a person executes to manage labour stressors fail, generating negative consequences for a worker, which might be seen as an illness or having the feeling of missing good health status with psychosomatic disorders, for example, suffering of cardio-respiratory alterations, headaches, gastritis and ulcer, sleeping difficulties, dizziness, etc., and for organization there might be seen as deterioration of performance or lower quality when assisting others or giving a service, absenteeism, no wanted rotation, abandonment, among others negative outcomes for the organization. $^{3}$

Consequences for worker's health may be classified as following: (a) subjective symptoms, such as tension headache, muscular tension, acidity, heart-beating, frigidity, impotence, the sense of respiration missing, irritability, difficulty to focus and memory loss; (b) behaviour changes, characterized as addictions to legal or illegal substances, sleeping problems (insomnia), labour absenteeism and selfesteem loss; (c) physical illnesses such as hypertension, phlebitis, acute myocardial infarction, colitis, gastritis, pruritus, eczema, psoriasis, dermatitis, asthmatic reactions, diseases related to immunologic system alterations, among others of physical type. ${ }^{4}$

Burnout is composed of three dimensions, which are: (a) emotional tiredness, which is characterized by a progressive energy loss, physical and psychological exhaustion, fatigue, physical wear and being at the edge feelings; (b) depersonalization, which constitutes by the deterioration in the quality of a service, a negative and insensible attitude against co-workers, in general, a worker's discomfort because of feelings of guiltiness and professional failure are the causes that originates this behaviour; and (c) a low personal fulfilment, which is the perception of professional achievements that are below personal expectations; having the feeling of being discontent about himself, being not motivated at work and dissatisfied with labour results, placed by feelings of inability, low self-esteem, low work effectivity and failure ideations, which suppose a negative self-qualification.

One of the contexts where Burnout is frequently manifested is where professionals have to give a reiterative assistance to clients who are in a problematic situation and where the demand that is required for the assistance is overload of emotional disturbance feelings, frustration, fear or desperation.,

Previous findings about Burnout syndrome affirm that, people suffering it are not solely the ones attending affective and emotional demands from other human beings, which means, it is not restrictive to professions dedicated to assistance such as medicine. ${ }^{6}$ This evidence gives a wide definition about Burnout, where chronic stress is not produced solely due to direct service to clients; instead, it might be produced in other labour contexts as well, being presented in management positions, commercial jobs, politics, administrative functions, teaching performance, among others. $^{6}$

Chemiss $^{7}$ proposes that a worker who is suffering of Burnout syndrome could experiment five phases according to presented symptomatology. The first phase of the syndrome is denominated enthusiasm, where an individual is starting in a new job position with a positive attitude, which generates enthusiasm and it is perceived as a stimulant feeling, wide energy and positive expectations to the new position is presented, to take into account, if the workday is extended or the labour conditions get complex, when a worker is in this first place, will take these events as challenges and not as problems.

The second phase is denominated as stagnation, where positive expectations are not seen to be accomplished by the worker generating doubts about the job position, when believing that, the relationship between effort and reward are imbalanced; because of it, expectations of the beginning are blurred, the interpretation of job's proposals are perceived as a threat and the worker feels he is incapable to respond in an efficient way. It is probable that in this phase some physical symptoms start appearing (headaches, stomach aches or boredom).

Frustration phase is the third one, in this phase is common that psychological tools that the worker has developed to cope frustration feelings, disappointment or demoralization are useful to overcome these difficult conditions, will serve to cope positively a situation where motivations, illusion for new projects take place; conversely, if these tools are not useful or not developed, it is possible to enter into a phase where psychosomatic problems are getting chronic; here, job does not mean anything, the worker presents an irritable attitude and may provoke conflicts with coworkers. In this phase health problems are presented and 
possible to recognize them, showing emotional, physiological and behavioural problems and difficulties.

The fourth phase is apathy, where defence mechanisms are presented in the individual, such as defensive - avoidant; which means the treat with other people is mechanized and cynic, which is related to the depersonalization concept; this same attitude is taken with stressing tasks, personal distance or withdrawal behaviour.

Burned phase is the fifth and last one of Burnout, where a physical, emotional and cognitive collapse is produced, which entails serious health problems, the worker presents a feeling of extreme exhaustion, experiencing emotional tiredness, and where syndrome is manifested with its most common and accentuated characteristics. Also, it is possible that the person feels the need of leaving the job, because of bad attitude and problems affecting in a direct and important way to his psychological health, plus the physical, provoking an unsatisfied and frustrated professional life, which would be fully related to low personal fulfilment.

It is important to mention that these phases are of a cyclic character, meaning that could be repeated in the same or different jobs or in different moments of a working life. ${ }^{7}$ In the same manner, it has been previously reported that a worker's psychological characteristics such as negative attitudes against the self, against others, guilty feelings and low frustration tolerance, are causing factors that increase statistically the probability that a worker present Burnout syndrome. ${ }^{8,9}$

In other studies it has been manifested the importance of doing follow-ups to worker's subjective symptoms, its behavioural changes, physical illnesses and emotional alterations, in order to diminish syndrome's impact on workers and to avoid experiencing deterioration in the last phases of Burnout.

As it has been possible to observe, the burned syndrome at work or Burnout, produce on who is suffering that working efficiency decreases, because this stress type makes that a worker's pertinence to the organization declines, in the treat to the client would show a lack of empathy, presenting health problems, and at the end, the contribution to the organization will be minimal.

In this context, it was necessary to realize a study on public servers; because in the daily routine of governmental organizations it is possible to observe that job's quality of people working there is deteriorated, being one of the possible causes of Burnout.

\section{Method}

The sample was composed of 121 public servers from Ecuador's labour system, who had in charge client's services in the realization of state legal paperwork. Gender, the sample was distributed in 46 females (38.02 per cent) and 75 males (61.98 per cent) aged among 24 and 58 years (Mage=36.21, SD=7.98). According to age frequency, 43 ( 35.5 per cent) belonged to the range between 24 to 31 years, 53 ( 43.8 per cent) belonged to the range between 32 to 42 years, and 25 (20.7 per cent) belonged to the range between 43 to 58 years. According to marital status, 65 (53.6 per cent) governmental workers were married, 36 (29.8 per cent) were single, 10 (8.3 per cent) divorced and 10 living together (8.3 per cent). According to educational level to which participants belonged, 11 (9.1 per cent) counted with secondary level, 97 (80.2 per cent) counted with university level and 13 (10.7 per cent) counted with postgraduate level. According to the pertinence to organization, 26 (21.5 per cent) had less than a year, 24 (19.8 per cent) had between 1 and 2 years, 24 (19.8 per cent) between 2 and 3 years, 19 (15.7 per cent) between 3 and 4 years, 16 (13.2 per cent) between 4 and 5 years, 12 (9.9 per cent) between 5 and 6 years.

\section{Materials}

Maslach Burnout Inventory General Survey (MBI-GS) was applied, this inventory has 16 items and, according to manual's directions, these are distributed in three subscales denominated as following: Low personal fulfilment (6 items), Emotional tiredness (5 items) and Depersonalization (5 items). Participants valued each item of the survey in a Liker-type scale that indicates the frequency of experiencing the situation described by the item. The frequency of the scale had 7 points which goes from 0 ("Never") to 6 ("Everyday"). This inventory had items like "I feel emotional exhausted because of my job" or "I feel burned out for my work", among others. ${ }^{10}$

\section{Data analyses and procedure}

The design for this study is not experimental, crosssectional, and with a quantitative approach. ${ }^{11}$ Data analyses were based on descriptive statistics of central tendency and dispersion. For inferential analyses correlation techniques, variance comparison and prediction of risk factors were applied. Quantitative analysis described before was conducted on the IBM SPSS statistical software package version 23 . 
At first, it was necessary to obtain the permission from the owner of the copyrights of the scale MBI-GS, which is Mind Garden, Inc. Editorial, once the permission was obtained for the utilization in this study, the instrument was applied. To get organizational permission, in the beginning governmental authorities were contacted and gave the approval to carry out this investigation. Then, public servers were invited to participate in the study, and those who accepted fill-out an informed consent to voluntary participate in the research. Questionnaires were applied by authors of the present study in a personalized manner and in an environment distraction free. It is important to note that throughout this study ethical standards for research with human beings declared on Helsinki were followed, there was signed an informed consent to voluntary participate and where they could withdraw at any time without any penalty, the information obtained from participants was confidential protected and throughout the research there was not risk for participants. ${ }^{4}$

\section{Results}

\section{Instrument's Reliability}

In Table 1, internal consistency values of each scale, correlation among each item and its descriptive values are presented.

Once internal consistency analysis was conducted, it was decided to eliminate item number 13 , because it did not count with a large contribution to Cronbach's Alpha coefficient and its correlation was minimal, in difference to the rest of the items from depersonalization scale.

Objective 1. Relationship among Burnout dimensions, time and position, and age of participants.

Analysis of relationship among Burnout levels consisted in executing a correlation among the three factors that composes the syndrome, it was found a correlation between medium and large among these factors, not significant when related to time and position, and significant in a minimal magnitude with worker's age (Table 2).

Objective 2. Frequency of workers according to Burnout's risk level. It was found that the greater percentage of workers belongs to a low risk of presenting Burnout syndrome, although, there is a percentage between 6 per cent and 20 per cent of workers that would present a greater probability of suffering this syndrome's symptomatology (Table 3).

Objective 3. Differences among factors composing Burnout.
Based on Maslach Burnout Inventory ${ }^{2}$ normalized punctuations, participants were organized in three groups according to the severity of Burnout's factor, next, there are three tables shown, where data of factors is presented as following (Tables 4-6).

Objective 4. Risk Factor according to participants' gender. To analyse risk probability according to participants' gender, emotional tiredness, low personal fulfilment, and depersonalization were codified as dichotomic variables and then, odds of risk to present Burnout symptomatology according to participants' gender were calculated (Table 7).

Objective 5. Comparison of Burnout factors according to worker's marital status and educational level.

To compare participants according to marital status and educational level, it was considered as comparison factors to each sublevel of these factors and the next step was to compare them with Burnout factors, where it was found that, marital status was not related to this syndrome, meanwhile, educational level has an incidence solely in low personal fulfilment (Tables 8 and 9).

\section{Discussion}

In this study it has been reported an investigation that had five objectives which analysed Burnout's relationship with different variables. The first objective was to analyse the existent relationship among emotional tiredness, depersonalization, low personal fulfilment and the worker's time in the position. It was possible to find that the factors composing Burnout are related and allow to identify that, even when belonging to a same construct, each one of them assess different aspects within factors composing Burnout.

Directly proportional correlation among emotional tiredness and depersonalization suggest that both variables increase hand to hand, it means, when a worker begins experiencing exhaustion in his emotional state, would start showing behavioural changes, such as a lack of empathy in the interaction with other people around him. On the other hand, inversely proportional correlation among low personal fulfilment and the two variables already mentioned would generate that while higher issues a worker presents on emotional tiredness and depersonalization, lower will be personal fulfilment experienced by a worker.

Taking into account the relationship among Burnout's dimensions and a worker's time on a position, it was not find a significant relation, which suggests that as it was reported on previous studies, ${ }^{12}$ different Burnout's 
dimensions would be present on a worker independently of the time that a worker is performing in the same position. Because of it, intervention processes to reduce the consequences of this syndrome must be applied on every worker, those already being part of the organization and the new ones.

The second objective was to identify the worker's frequency on the different Burnout's levels, to accomplish it, it was necessary to take as values of reference the ones described on MBI-GS manual ${ }^{2}$ that determined syndrome's severity level, which allowed to identify that there is an existent percentage of workers between 5 per cent and 20 per cent who present a high risk level of suffering this syndrome, because of it, health authorities must take into consideration decision making, according to prevent and intervene on the three factors composing Burnout on workers.

Is important to mention that, these data are in concordance with other investigations conducted previously in other countries, such as Spain and Mexico, where it has been reported percentages among 15.7 per cent and 40.9 per cent of health services workers who present high severity levels of emotional tiredness, among 18.5 per cent and 43.5 per cent of workers presenting high severity levels of depersonalization, and among 25.8 per cent and 31.8 per cent presenting high probability of presenting low personal fulfilment. ${ }^{13-15}$

The third objective was to determine differences among levels of Burnout's three factors, where statistically significant contrasts were found, workers presenting higher severity of emotional tiredness, depersonalization and low personal fulfilments were who presented higher deterioration of chronic stress symptomatology on labour context and to whom a mental health intervention will be positive to improve a government organization productivity.

The fourth objective planned to analyse the probability of presenting Burnout syndrome according to participants' gender; it was found that male gender is a risk factor to present low personal fulfilment, evidencing 1.44 more times of presenting this symptomatology. On depersonalization risk, also males present 1.12 times more probabilities of presenting depersonalization symptoms. Instead, emotional tiredness, females presents 1.39 times a higher risk to present this symptomatology on this Burnout factor; these results are concordant with the ones reported on a study conducted previously in Mexico. ${ }^{15}$
The fifth objective of this study had as a goal to contrast each factor of Burnout according to marital status and educational level of participants, results showed that educational level is related to Burnout, where workers with a lower academic instruction experienced higher low personal fulfilment symptomatology, comparing with participants who had higher academic instruction such as university or postgraduate level, who show better personal fulfilment levels, which means that academic achievements and advances will bring positive results on public servers' personal fulfilment.

Results described previously must be considered according to Ecuador's frame, which is a Latin American country with more than sixteen people of population, with a capitalist economical system, its currency is United States dollar, the majority of the population belongs to Roman Catholic religion and has a labour system based on occidental context. These characteristics of Ecuador allow the results presented in this research to serve as a reference to the understanding of Burnout's syndrome on the laboral context of countries which share similar characteristics as the ones previously mentioned.

As limitations of this study is important to mention that the sample size must be considered with the condition of being exploratory, as it is the study reported in this article. Nevertheless, these data allows identifying the need to take into consideration workers' mental health as risk factor of for a global healthy state of human being.

Even when this is a limitation element of this study, this condition generates the need for future research where sample size must be higher than the one reported in this article from Ecuador's laboral context. Also, there is the genuine interest to implement intervention projects in order to diminish the impact of work-stress related on Ecuadorian workers.

\section{Conclusion}

As it has been described throughout this article, Burnout syndrome affects to an important public servers' percentage, in this sense, future investigation from this study is psychotherapeutic intervention on workers who present high punctuations of Burnout and the possibility to determine the efficacy of a psychological treatment process for this syndrome. 


\section{References}

1. Freudenberger H. Staff Burnout. Journal of Social Issues. 1974;30(6):159-165. doi: 10.1111/j.15404560.1974.tb00706.x.2.

2. Maslach C, Jackson E. MBI: Maslach Burnout Inventory. Manual Palo Alto: University of California, Consulting Psychologists Press; 1996.

3. Shiron, A. Burnout in Work Organization. International Review of Industrial and Organizational Psychology; New York: Wiley Press; 2003.

4. Fidalgo M. Síndrome de estar quemado por el trabajo o "Burnout" (I): definición y proceso de generación. Instituto Nacional de Seguridad e Higiene en el Trabajo de España (INSHT), NTP 704. España; 2006.

5. Llaneza F. Ergonomía y psicosociología aplicada. Editorial Lex Nova S.A. Valladolid-España; 2006. Available from: www.insht.es/InshtWeb/Contenidos/Documentacion/Fi chasTecnicas/NTP/Ficheros/701a750/ntp_704.pdf

6. Jiménez J, Betancor L. El síndrome de Burnout como riesgo Psicosocial. Universitat Politécnica de Catalunya; 2009.

7. Russek S. Poca tolerancia a la frustración. Crecimiento y bienestar emocional: Mejorando el presente, enriqueciendo el futuro. Recuperado de Internet de: Available from: www.crecimiento-y-bienestaremocional.com/frustracion.html; 2007.

8. De Los Ríos J, Ocampo M, Landeros $\mathrm{M}$, et al. Burnout en Personal Administrativo de una Dependencia Gubernamental: Análisis de sus Factores Relacionados. Revista Investigación y ciencia de la Universidad Autónoma de Aguascalientes. 2007;37.

9. Hernández R, Fernández C, Baptista M. Metodología de la investigación. Quinta edición. Mcgraw-Hill / Interamericana Editores, S.A. DE C.V. México DF; 2010.

10. Gil-Monte P, Peiró J. Desgaste psíquico en el trabajo: el síndrome de quemarse. Madrid: Síntesis; 1997.

11. Buendía J, Ramos F. Empleo, Estrés y Salud. Madrid: Pirámide; 2001.

12. World Medical Association. Declaration of Helsinki. Ethical principles for medical research involving human subjects. JAMA. 2013;310(20):2191-4. doi: 10.1001/jama.2013.2810

13. Sanjuan L, Arrazola O, García L. Prevalencia del Síndrome del Burnout en el personal de enfermería del Servicio de Cardiología, Neumología y Neurología del Hospital San Jorge de Huesca. Revista Enfermería Global. 2014;36: 253-264. doi: 10.6018/eglobal.13.4.192071

14. Navarro-González D, Ayechu-Díaz A, Huarte-Labiano I. Prevalencia del síndrome del burnout y factores asociados a dicho síndrome en los profesionales sanitarios de salud primaria. Revista Medicina de Familia
SEMERGEN.

$2015 ; 41(4)$.

doi:

10.1016/j.semerg.2014.03.008.

15. Castañeda E, García J. Prevalencia del síndrome de agotamiento profesional (Burnout) en odontólogos de una institución educativa y de salud, en la ciudad de Guadalajara, México en 2012. Revista Facultad de Odontología Universidad de Antioquia. 2012;24(2):267288.

\section{ACKNOWLEDGEMENTS}

Authors of the present research express gratitude to workers who participated and contributed in this study by completing the test Maslach Burnout Inventory General Survey.

\section{PEER REVIEW}

Not commissioned. Externally peer reviewed.

\section{CONFLICTS OF INTEREST}

The authors declare that they have no competing interests.

\section{FUNDING}

This study did not require an external funding resource.

\section{ETHICS COMMITTEE APPROVAL}

This study was approved by the Ethical Committee of the Indoamerica Technology University of Ecuador. 
Table 1: Applied instrument's reliability parameters

\begin{tabular}{|l|l|l|l|l|l|l|l|}
\hline Burnout Scale & $\mathbf{A}$ & $\mathbf{r}_{\mathrm{jx}}$ & $\boldsymbol{\alpha}$-j & Mean & SD & Min & Max \\
\hline Emotional Tiredness & 0.85 & $0.59-0.69$ & $0.79-0.82$ & 7.25 & 4.58 & 0 & 20 \\
\hline Professional Realization & 0.84 & $0.51-0.74$ & $0.79-0.81$ & 6.57 & 5.35 & 0 & 25 \\
\hline \multirow{2}{*}{ Depersonalization } & 0.83 & $0.65-0.80$ & $0.75-0.81$ & $3.52(6.57)$ & 4.43 & 0 & 20 \\
& $(0.79)$ & $(0.24-0.68)$ & $(0.65-0.84)$ & & $(5.35)$ & $(0)$ & $(25)$ \\
\hline
\end{tabular}

Note. Scale's Alpha ( $\alpha$ ), correlations item-total (rjx) and Cronbach's Alpha if the element were removed $(\alpha-j)$. In depersonalization, among parenthesis is data considering every scale's item, and, without parenthesis reliability values removing item 13

Table 2: Correlation among Burnout's factors

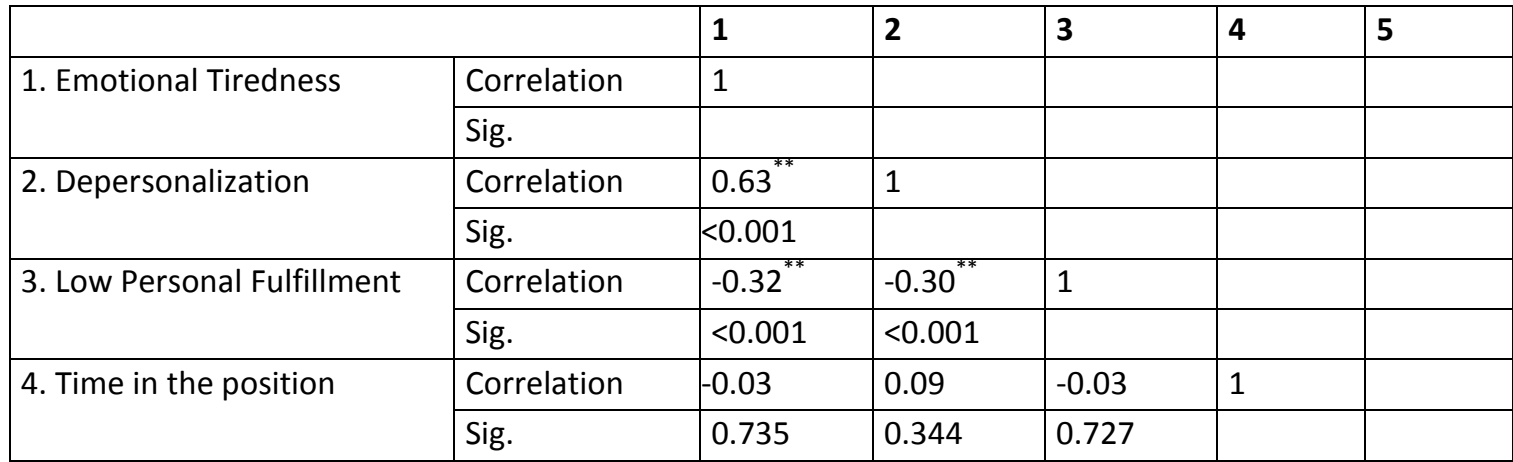

**. Correlation is significant at level .01 (bilateral)

*. Correlation is significant at level .05 (bilateral)

Table 3: Frequency of workers on different levels of Burnout

\begin{tabular}{|l|l|l|l|l|l|l|}
\hline $\begin{array}{l}\text { Burnout's } \\
\text { risk level }\end{array}$ & $\begin{array}{l}\text { Frequency } \\
\text { ET }\end{array}$ & $\begin{array}{l}\text { Percentage } \\
\text { ET }\end{array}$ & $\begin{array}{l}\text { Frequency } \\
\text { LPF }\end{array}$ & $\begin{array}{l}\text { Percentage } \\
\text { LPF }\end{array}$ & $\begin{array}{l}\text { Frequency } \\
\text { D }\end{array}$ & $\begin{array}{l}\text { Percentage } \\
\text { D }\end{array}$ \\
\hline High & 6 & 5.0 & 9 & 7.40 & 25 & 20.70 \\
\hline Moderate & 26 & 21.50 & 21 & 14.40 & 37 & 30.60 \\
\hline Low & 89 & 73.60 & 91 & 75.20 & 59 & 48.80 \\
\hline
\end{tabular}

Note: ET (Emotional Tiredness), LPF (Low Personal Fulfilment), D (Depersonalization). In the next tables, values that determine the inclusion of workers in each risk group are described

Table 4: Burnout factors according to severity level: Emotional Tiredness

\begin{tabular}{|l|l|l|l|l|l|}
\hline \multirow{2}{*}{ Emotional Tiredness } & \multirow{4}{*}{ Mean } & \multirow{2}{*}{ Standard deviation } & \multicolumn{2}{|l|}{ 95\% Confidence Interval for the mean } & Comparison \\
\cline { 5 - 6 } & & Lower Limit & Upper Limit & ANOVA \\
\hline High & 17.83 & 1.84 & 15.91 & 19.76 & F $=158.80$ \\
\hline Moderate & 12.50 & 1.21 & 12.01 & 12.99 & $p<0.001$ \\
\hline Low & 5.00 & 2.68 & 4.44 & 5.56 & \\
\hline
\end{tabular}

Note. Punctuations which determined the three severity levels of emotional tiredness were: High 16 points or more, Moderate: 11 to 15 points and Low: from 0 to 10 points 
Table 5: Burnout Factors according to severity level: Low Personal Fulfilment

\begin{tabular}{|c|c|c|c|c|c|}
\hline \multirow{2}{*}{$\begin{array}{l}\text { Low Personal } \\
\text { Fulfilment }\end{array}$} & \multirow[b]{2}{*}{ Mean } & \multirow{2}{*}{$\begin{array}{l}\text { Standard } \\
\text { deviation }\end{array}$} & \multicolumn{2}{|l|}{$95 \% \mathrm{Cl}$} & \multirow{2}{*}{$\begin{array}{l}\text { Comparison } \\
\text { ANOVA }\end{array}$} \\
\hline & & & $\begin{array}{l}\text { Lower } \\
\text { Limit }\end{array}$ & $\begin{array}{l}\text { Upper } \\
\text { Limit }\end{array}$ & \\
\hline High & 33.53 & 2.01 & 33.11 & 33.95 & $F=238.39$ \\
\hline Moderate & 27.14 & 1.2 & 26.6 & 27.69 & $p<0.001$ \\
\hline Low & 18.78 & 4.44 & 15.37 & 22.19 & \\
\hline
\end{tabular}

Note. Punctuations encompassing each group are as following: High 30 or more points, Moderate from 24 to 29 points, and Low from 0 to 23 points (is important to take on account in this variable that lower punctuations mean higher personal fulfilment problems). $\mathrm{Cl}=$ Confidence Interval.

Table 6: Burnout Factors according to severity level: Depersonalization

\begin{tabular}{|l|l|l|l|l|l|}
\hline \multirow{2}{*}{$\begin{array}{l}\text { Depersona- } \\
\text { lization }\end{array}$} & \multirow{3}{*}{$\begin{array}{l}\text { 95\% Confidence Interval for } \\
\text { the mean }\end{array}$} & $\begin{array}{l}\text { Comparison } \\
\text { ANOVA }\end{array}$ \\
\cline { 3 - 6 } & Mean & $\begin{array}{l}\text { Standard } \\
\text { deviation }\end{array}$ & $\begin{array}{l}\text { Lower } \\
\text { Limit }\end{array}$ & $\begin{array}{l}\text { Upper } \\
\text { Limit }\end{array}$ & \\
\hline High & 10.80 & 3.86 & 9.21 & 12.39 & $\mathrm{~F}=176.54$ \\
\hline Moderate & 2.92 & 2.14 & 2.21 & 3.63 & $p<0.001$ \\
\hline Low & 0.81 & 1.09 & 0.53 & 1.10 & \\
\hline
\end{tabular}

Note. Depersonalization level is High when the punctuation is of 11 or more points, Moderate when is between 6 and 10 points and Low when it is between 0 and 5 points

Table 7: Analysis of gender as risk factor

\begin{tabular}{|l|l|l|}
\hline Burnout's factor & Odds Ratio & Confidence Interval 95\% \\
\hline Emotional Tiredness & M. vs. F. 1.39* & $0.61-3.15$ \\
\hline Low Personal Fulfilment & M. vs. F. 1.44* & $0.69-3.00$ \\
\hline Risk of Depersonalization & M. vs. F. 1.12* & $0.48-2.60$ \\
\hline
\end{tabular}

${ }^{*} p<0.05$. M=Male, F=Female

Table 8: Comparison of Burnout's factors according to worker's marital status

\begin{tabular}{|l|l|l|l|l|}
\hline \multicolumn{2}{|c|}{} & Mean & $\begin{array}{l}\text { Standard } \\
\text { deviation }\end{array}$ & $\begin{array}{l}\text { Comparison } \\
\text { ANOVA }\end{array}$ \\
\hline \multirow{4}{*}{ Emotional Tiredness } & Single & 7.61 & 4.27 & $\mathrm{~F}=0.28$ \\
\cline { 2 - 5 } & Divorced & 7.4 & 5.3 & $\mathrm{p}=0.84$ \\
\cline { 2 - 5 } & Married & 6.91 & 4.65 & \\
\cline { 2 - 5 } & Living together & 8 & 5.1 & \\
\hline \multirow{5}{*}{ Depersonalization } & Single & 4.25 & 5.09 & $\mathrm{~F}=1.93$ \\
\cline { 2 - 5 } & Divorced & 5.2 & 4.49 & $\mathrm{p}=0.12$ \\
\cline { 2 - 5 } & Married & 2.66 & 3.67 & \\
\cline { 2 - 5 } & Living together & 4.8 & 5.77 & $\mathrm{~F}=0.15$ \\
\hline Low Personal & Single & 31.08 & 5.54 & $\mathrm{p}=0.93$ \\
\hline \multirow{5}{*}{ Fulfilment } & Divorced & 31.9 & 2.81 & \\
\cline { 2 - 5 } & Married & 31.46 & 4.61 & 5.38 \\
\cline { 2 - 5 } & Living together & 30.7 & & \\
\hline
\end{tabular}


Table 9: Comparison of Burnout's factors according to worker's educational level

\begin{tabular}{|l|l|l|l|l|}
\hline \multicolumn{2}{|c|}{} & Mean & $\begin{array}{l}\text { Standard } \\
\text { deviation }\end{array}$ & $\begin{array}{l}\text { Comparison } \\
\text { ANOVA }\end{array}$ \\
\hline \multirow{3}{*}{ Emotional Tiredness } & Secondary Level & 5.27 & 2.87 & $\mathrm{~F}=1.31$ \\
\cline { 2 - 5 } & University Level & 7.35 & 4.67 & $\mathrm{p}=0.28$ \\
\cline { 2 - 5 } & Postgraduate Level & 8.15 & 4.95 & \\
\hline \multirow{3}{*}{ Depersonalization } & Secondary Level & 2.18 & 2.36 & $\mathrm{~F}=0.64$ \\
\cline { 2 - 5 } & University Level & 3.59 & 4.64 & $\mathrm{p}=0.53$ \\
\cline { 2 - 5 } & Postgraduate Level & 4.15 & 4.2 & \\
\hline \multirow{3}{*}{ Low Personal Fulfilment } & Secondary Level & 27.36 & 8.5 & $\mathrm{~F}=4.33$ \\
\cline { 2 - 5 } & University Level & 31.71 & 4.24 & $\mathrm{p}=0.02$ \\
\cline { 2 - 5 } & Postgraduate Level & 31.77 & 3.42 & \\
\hline
\end{tabular}

